\title{
Forest land use discontinuity and northern red oak Quercus rubra introduction change biomass allocation and life strategy of lingonberry Vaccinium vitis-idaea
}



\begin{abstract}
Background: Multi-purpose use of forests in a sustainable way forces a recognition of how introduction of alien woody species in forests with different land use histories affect native plants other than trees. Lingonberry Vaccinium vitis-idaea is an important understory component of temperate and boreal forests and provider of valuable non-wood forest products. Here we studied effects of land use changes and introduction of Northern red oak Quercus rubra on lingonberry in mesic Scots pine forests (in central Poland). We measured lingonberry cover, height of shoots, biomass of stems and leaves, and fruit productivity. Shoots were collected within 200 research plots located in recent and ancient Scots pine forests, with and without Q. rubra.

Results: We found that $V$. vitis-idaea reached lower cover, aboveground biomass and fruit production in recent than ancient forests and in forests with than without $Q$. rubra. The fruit production in recent pine forest was only $2 \%$ of that reported in ancient pine forest, and $V$. vitis-idaea did not reproduce generatively in forests with $Q$. rubra. Biomass and carbon sequestration of $V$. vitis-idaea in forests with alien (invasive) trees decreased by $75 \%$ compared to ancient pine forest. Effects were also clear at the individual shoot level - in less suitable conditions we found taller heights and higher biomass allocation into stems than foliage. Biomass allocation in fruiting and non-fruiting shoots in pine forests was also different - less of the dry biomass of fruiting shoots was allocated to leaves than to stems.
\end{abstract}

Conclusions: In the age of high interest in ecosystem services and discussions about usage of alien tree species as alternatives in forest management, our results clearly indicate disruption of ecosystem services provided by $V$. vitisidaea in the presence of Q. rubra. Lingonberry benefited from the continuity of forest land use, however, regardless of land-use legacy, alien tree introduction led to decline in abundance of species crucial for ecosystem functioning. Therefore, to maintain valuable native species and for conservation of ecosystem services delivery, we suggest limiting the introduction of $Q$. rubra in areas with abundant $V$. vitis-idaea, especially in forests with continuous forest land-use history.

Keywords: Ancient and recent forest, Understory biomass, Ecosystem services, Invasive tree, Lingonberry, Non wood forest products, Red oak introduction, Scots pine monoculture

\footnotetext{
* Correspondence: beata.woziwoda@biol.uni.lodz.pl

${ }^{1}$ Faculty of Biology and Environmental Protection, Department of Geobotany and Plant Ecology, University of Lodz, Banacha 12/16, PL-90-237 Łódź, Poland Full list of author information is available at the end of the article
}

\section{Springer Open}

(c) The Author(s). 2021 Open Access This article is licensed under a Creative Commons Attribution 4.0 International License, which permits use, sharing, adaptation, distribution and reproduction in any medium or format, as long as you give appropriate credit to the original author(s) and the source, provide a link to the Creative Commons licence, and indicate if changes were made. The images or other third party material in this article are included in the article's Creative Commons licence, unless indicated otherwise in a credit line to the material. If material is not included in the article's Creative Commons licence and your intended use is not permitted by statutory regulation or exceeds the permitted use, you will need to obtain permission directly from the copyright holder. To view a copy of this licence, visit http://creativecommons.org/licenses/by/4.0/. 


\section{Background}

The forest understory layer contains the majority of species richness within temperate and boreal forest ecosystems (Whigham 2004; Gilliam 2007), including numerous plants which are a source of a valuable nonwood forest products (NWFPs; Laird et al. 2010) and are important for delivery of forest ecosystem services (MEA 2005; Landuyt et al. 2019). The composition and vitality of plants in shrub, herb and moss layers strongly depend on tree stand composition and overstory canopy closure (Barbier et al. 2008; Wagner et al. 2011; Hedwall et al. 2013). Diverse forestry measures are implemented to modify the understory (Reicis et al. 2020), however, their main aim is to improve regeneration and growth of selected (commercially important) tree species (Pretzsch 2009). The multi-purpose use of forests in sustainable ways forces a recognition of how any management activities affect forest components other than trees (Felton et al. 2016; Sutherland et al. 2016). The growing interest in NWFPs (Vidale et al. 2014; Wiersum et al. 2018) raises the question of how to manage forests and maintain valuable plant species (Chamberlain et al. 2019), and even how to increase productivity of plants in the wild (Miina et al. 2010; Pettenella et al. 2019), to meet rising demand within the frames of sustainability (Wolfslehner 2019). The conservation of understory components is also important with regard to the loss of native biodiversity (Hunter 1999; CBD 2010).

One of the important sources of NWFPs is lingonberry (cowberry) Vaccinium vitis-idaea. This long-lived dwarf shrub (Ericaceae family) occurs naturally in circumboreal areas, in northern Eurasia and North America (Luby et al. 1991). It is a clonal plant with aboveground leafy shoots and underground rhizomes (Ritchie 1955). Lingonberry reproduces sexually, and more often asexually, by clonal growth. It fruits from August to October producing strongly flavoured, red fleshy berries, with 5-8 seeds dispersed by frugivorous animals. Lingonberry is a source of food and water for birds (Jacquemart and Thompson 1996) and mammals (e.g. Baltrūnaitė 2001; Jaroszewicz et al. 2008; Krasnov et al. 2015). Numerous insects and other invertebrate species also feed on $V$. vitis-idaea, and use lingonberry dwarf-shrubs as shelter. Insects feed on lingonberry nectar and pollen, simultaneously being important pollinators (Stephens 2012).

The arbutin-containing leaves and fruits of $V$. vitisidaea, rich in micronutrients, flavonoids and other phenolics, are used as a valuable herbal (medicinal) material and healthy food (Yao and Vieira 2007; Kylli et al. 2011; Radusheva et al. 2017). Row lingonberries and their preserves (juices, syrups, jams, etc.) are commonly consumed, and in Canada and the Scandinavian countries lingonberries are a distinctive ingredient of national cuisines (Hjalmarsson and Ortis 2001; Turtiainen et al. 2011). Lingonberry picking in the wild is a part of the rural lifestyle (Pouta et al. 2006), and as a part of the regional culture and tradition and an attractive form of recreational activity, it can favour the development of a local tourism industry (Górriz 2019).

Centuries of traditional use of $V$. vitis-idaea have contributed to the high interest in this species, which is currently enhanced by the growing fascination with ecological lifestyles and nature-based health foods (Šišák et al. 2016; Hamunen et al. 2019; Tahvanainen et al. 2019). Berries and their preserves are sold both in domestic and international markets. The trade of fresh fruits and plants harvested in the wild is an important source of additional income to rural households, contributing to livelihoods and well-being of local communities (Turtiainen et al. 2011; Vidale et al. 2015). Lingonberry picking for private and national companies is a way of earning money for seasonal workers, including foreigners (Peltola et al. 2014; Huber et al. 2017; Hamunen et al. 2019). The growing lingonberry market demand since the 1980's (Burt and Penhallegon 2003) favoured the development of $V$. vitis-idaea commercial plantations with selection and use of over twenty cultivars (Hjalmarsson and Ortis 2001; Debnath and McRae 2001; Penhallegon 2006). However, in Central and Northern Europe most of the lingonberries are still harvested in the wild (Seeland and Staniszewski 2007; Manninen and Peltola 2013).

Lingonberry prefers mesic to dry sites with acid soils and sand-loamy or rocky substrates (Ellenberg et al. 2001). The soil is poor in nutrients, however, a thin layer of organic matter is usually deposited nearby shoots, or the ground is covered by a dense moss layer. $V$. vitisidaea grows best with little competition from other herbal plants (Timoshok 2000); in mesic sites it often co-occurs with bilberry $V$. myrtillus (Mäkipää 1999). In Europe it is commonly noted in mesic to dryish (subxeric) coniferous forests dominated by Scots pine Pinus sylvestris (Matuszkiewicz 2001; Turtiainen et al. 2013). It also occurs in light deciduous oak forests with pedunculate Quercus robur or sessile oak Q petraea, in marginal types of forest (e.g. fell forests), as well on pristine and drained peatland sites (Kardell 1980; Matuszkiewicz 2001). Although V. vitis-idaea is widespread and commonly noted and the International Union for Conservation of Nature assesses lingonberry as a species of "Least Concern" (Maiz-Tome 2016), its decline in some parts of the natural range, e.g. in Poland (Zarzycki et al. 2002), has been observed. At present not more than $10 \%$ of wild $V$. vitis-idaea resources are harvested in countries which are the main lingonberry producers and consumers (Manninen and Peltola 2013), and probably much less in the others, so overexploitation of wild 
populations is not the reason for decline of this species. Studies show that the serious threat to some Vaccinium species comes from the transformation of Scots pine forest to mixed forests (Matuszkiewicz et al. 2013; Turtiainen 2015; Woziwoda et al. 2019b). The intentional underplanting of deciduous trees or their spontaneous encroachment into coniferous monocultures causes changes in habitat conditions (Collier and Farrell 2007; Wagner et al. 2011, and references therein; Dyderski and Jagodziński 2019b) which become unfavourable to light-demanding and oligotrophic ericaceous plants.

Here we studied lingonberry in mesic pine forests occupied by mixed Scots pine-Northern red oak stands and by Scots pine monocultures. Quercus rubra, introduced to Europe from North America (Magni Diaz 2004), has been commonly planted in coniferous monocultures to increase tree stand biodiversity (Woziwoda et al. 2014c; Nicolescu et al. 2018). This alien deciduous tree admixture was used to "enrich" both postagricultural pine monocultures planted on former arable lands (recent forests, RF, sensu Peterken 1974), as well as pine stands planted in forest clearings (ancient forests, AF). However, growing in high density, Q. rubra negatively impacts other plant species (e.g. Marozas et al. 2009; Woziwoda et al. 2014a; Chmura 2020) and because of that it is noted in some European countries as an invasive tree (Dyderski et al. 2020, and references therein). Studies on Vaccinium myrtillus revealed that in the presence of Q. rubra, biomass allocation to shoots is modified and berry production significantly decreases (Woziwoda et al. 2019b), despite the fact that bilberry is a plant with a relatively wide range of ecological tolerance to habitat conditions and their changes (Nestby et al. 2011). The question was, how has Q. rubra introduction affected the understory component strongly associated with light coniferous stands?

We aimed to assess biomass and fruit productivity of $V$. vitis-idaea in Scots pine forests differing by management history (ancient vs. recent), with and without $Q$. rubra. We hypothesized that $V$. vitis-idaea: (1) will reach the highest cover in the least transformed forests where it will co-dominate with other understory species typical of natural Scots pine forests; (2) will reach higher biomass and height in the least transformed forests and will allocate more biomass into foliage than to stems; and (3) will produce fewer fruits in the more transformed forests. We also hypothesized that (4) fruiting and non-fruiting shoots will differ in biomass allocation, (5) higher investment in reproductive organs will be compensated by lower biomass allocation into foliage rather than to stems, and (6) these relationships will be modified by forest type (i.e. forest transformation gradient).

\section{Materials and methods Study area}

The field study was conducted in August-September 2016, in commercial forests located in central Poland (in the Aleksandrówek forest complex: $51.8599^{\circ} \mathrm{N}, 18.9912^{\circ}$ $\mathrm{E}$, ancient forest (AF), and the Małyń-Jerwonice forest complex: $51.7803^{\circ} \mathrm{N}, 19.0455^{\circ} \mathrm{E}$, recent forest (RF), ca $10 \mathrm{~km}$ from the ancient forest). Research plots were located in the same forest fragments, which were previously chosen for $V$. myrtillus studies (Woziwoda et al. 2019b). The ancient pine forest (AF) was an 86-year-old P. sylvestris monoculture, and a fragment of which was enriched 50 years ago with alien Q. rubra. The recent pine forests (RF) were: a 69-year-old monoculture of $P$. sylvestris and, adjacent to it, a 100-year-old stand of $P$. sylvestris with introduced 35-year-old $Q$. rubra. The $Q$. rubra formed a dense and continuous canopy in the lower tree stand layer (below the Scots pine crowns), both in ancient and recent forests. Juveniles of Q. rubra as well as other deciduous tree species like rowan Sorbus aucuparia, alder buckthorn Frangula alnus, silver birch Betula pendula and pedunculate oak Q. robur occurred in the shrub layer of the studied forests. The vascular plant layer was dominated by ericaceous dwarf shrubs and grasses. The moss layer covered almost all the ground in both pine forests, but was scarce in forests with Q. rubra (more information on the tree stand structure was included in Woziwoda et al. 2019b). Lingonberry occurred in the Scots pine forests over the continuous moss layer, while in mixed forests it grew on soil covered by litter layer of red oak leaves and pine needles.

\section{Field and lab studies}

Phytosociological relevés (15 per variant; 60 in total), each $100 \mathrm{~m}^{2}$ in area, were conducted (using the BraunBlanquet method) in August 2016 to estimate lingonberry cover and to identify patterns of $V$. vitis-idaea abundance in the forest variants studied. The lingonberry ground cover and shoot density were estimated in 200 research plots (each $0.25 \mathrm{~m}^{2}$ in area), which were set up in each of the two localities in the Scots pine forests with and without Q. rubra. Ten shoots, randomly chosen within each research plot (200 samples in total), were collected to measure the biomass of stems, leaves and fruits, as well as shoot height and productivity (the number of fruits growing on a shoot). The fresh and dry mass of leaves, stems and fruits was compared in detail for 100 shoots collected in each forest variant studied. Applied methods were similar to a previous $V$. myrtillus study (Woziwoda et al. 2019b).

As no lingonberry fruiting shoots were found in field plots with Q. rubra, berry production was studied exclusively in the Scots pine monocultures. Due to the low 
number or lack of fruiting shoots collected within research plots, additional samples (up to 100 shoots for each) were collected to compare lingonberry yield in forests growing on reforested and afforested areas, as well to compare fresh biomass allocation in fruiting and nonfruiting shoots. Then, we used mean water content to calculate dry fruit mass in other plots. For comparison of randomly selected fruiting and non-fruiting ramets we measured their fresh mass, and then we calculated dry mass using mean water content from ten randomly selected shoots per forest type and fruiting or non-fruiting variant (Table 1).

\section{Data analysis}

We conducted all analyses using R software, v. 3.5.3 (R Core Team 2019). ANOVA was used to assess differences in mean cover among forest types studied and we used Tukey posteriori tests with multiple hypotheses studentized adjustment. We assessed patterns of understory species co-occurrence using phytosociological relevés and detrended correspondence analysis (DCA; Hill and Gauch 1980). DCA is an ordination method based on correspondence analysis between species and sites. In contrast to correspondence analysis, DCA is robust to long environmental gradients due to standardizing site and species scores using standard deviation units. We conducted DCA using the vegan::decorana() function (Oksanen et al. 2018). We also showed gradients of vegetation structure descriptors (covers of vegetation layers, as well as $P$. sylvestris and Q. rubra canopy) using passive projection of vectors, implemented in the vegan:: envfit() function (Oksanen et al. 2018).

In the dataset of individual measurements we assessed the effects of land-use type (ancient forest vs. recent forest) and Q. rubra using linear mixed-effects models (LMMs), developed using the lme4 package (Bates et al. 2015; Kuznetsova et al. 2017). We accounted for study plots and interaction between plot and variant as random effects, to exclude plot-specific effects. In the dataset of plot-level data, as well as for comparison of randomly selected fruiting and non-fruiting individuals we used linear regression, with the exception of density and fruit production. For those we used generalized

Table 1 Mean (+SE) water content (\%) in stems (ST) and foliage $(\mathrm{FL})$ of randomly sampled lingonberries ( $n=10$ per treatment) and mean water content (\%) in 100 fruits (FR) $(n=10$ per treatment), in ancient (AF) and recent (RF) pine forests

\begin{tabular}{llllllll}
\hline Forest & Shoots & ST & SE & FL & SE & FR & SE \\
\hline AF & Fruiting & 46.13 & 0.74 & 53.24 & 0.99 & 76.78 & 0.87 \\
AF & Non-fruiting & 38.61 & 2.04 & 32.49 & 0.96 & - & - \\
RF & Fruiting & 46.90 & 2.16 & 54.26 & 0.58 & 85.00 & 0.27 \\
RF & Non-fruiting & 44.78 & 1.33 & 43.88 & 2.03 & - & - \\
\hline
\end{tabular}

linear models (GLMs) assuming negative binomial and zero-inflated Poisson distributions, respectively. For density analysis we decided to use negative binomial GLM due to high overdispersion ( 10) of Poisson GLM, while for fruit production we decided to use zeroinflated Poisson GLM due to high number of non-fruit producing individuals. Zero-inflated Poisson GLM was implemented using the pscl::zeroinfl() function (Zeileis et al. 2008) and negative binomial GLM using the MASS:::glm.nb() function (Venables and Ripley 2002). We evaluated differences between variants using Tukey posteriori tests with studentized adjustment for multiple hypothesis testing, implemented in the emmeans::emmeans() function (Lenth 2019). We assessed ecosystem-level aboveground and fruit dry biomass, as well as water and carbon storage of $V$. vitis-idaea in the pine forest variants, using mean cover of $V$. vitis-idaea in phytosociological relevés, similarly to Woziwoda et al. (2019b). Despite bias connected with visual estimation and cover scale resolution, it was necessary for the correction of abundance from small to large-scale due to growth strategy (clumps). To assess carbon sequestration we used carbon concentration in $V$. vitis-idaea of $44.5 \%$, obtained in post-agricultural forests on the same soil type as in our study, located c. $4.5 \mathrm{~km}$ from the Aleksandrówek forest complex (Woziwoda et al. 2014b).

Study limitations: We are aware that conclusions drawn from our study might be biased by the low replicability (connected with very high labour demand) - each forest type is represented by only one study site and research plots are probably not independent. This may limit the transferability of the results and one should be cautious when inferring results and conclusions for other forests. However, despite the lack of replications, assessments of effects of introduced (invasive) woody species on biomass of native plants in forests with different histories of land use (recent vs. ancient) are scarce, and our study provides novel data which could be used in designing further studies.

\section{Results}

\section{Patterns of lingonberry occurrence and abundance}

Vaccinium vitis-idaea reached the highest cover in ancient pine forests $(27.1 \% \pm 1.3 \%)$, lower $(13.7 \% \pm 0.8 \%$; ANOVA $\mathrm{df}=3, F=19.07, p<0.0001)$ in recent pine forests, and the lowest - in ancient and recent forests with Q. rubra $(0.16 \% \pm 0.01 \%$ and $0.03 \% \pm 0.03 \%$, respectively).

Analysis of co-occurring species revealed that $V$. vitisidaea preferred sites dominated by $P$. sylvestris canopy, not occupied by Q. rubra (Fig. 1, Table 2). The studied species co-occurred with natural regeneration of $P$. sylvestris and $B$. pendula, in sites with high cover of bryophytes (mainly Pseudoscleropodium purum, Pleurozium 


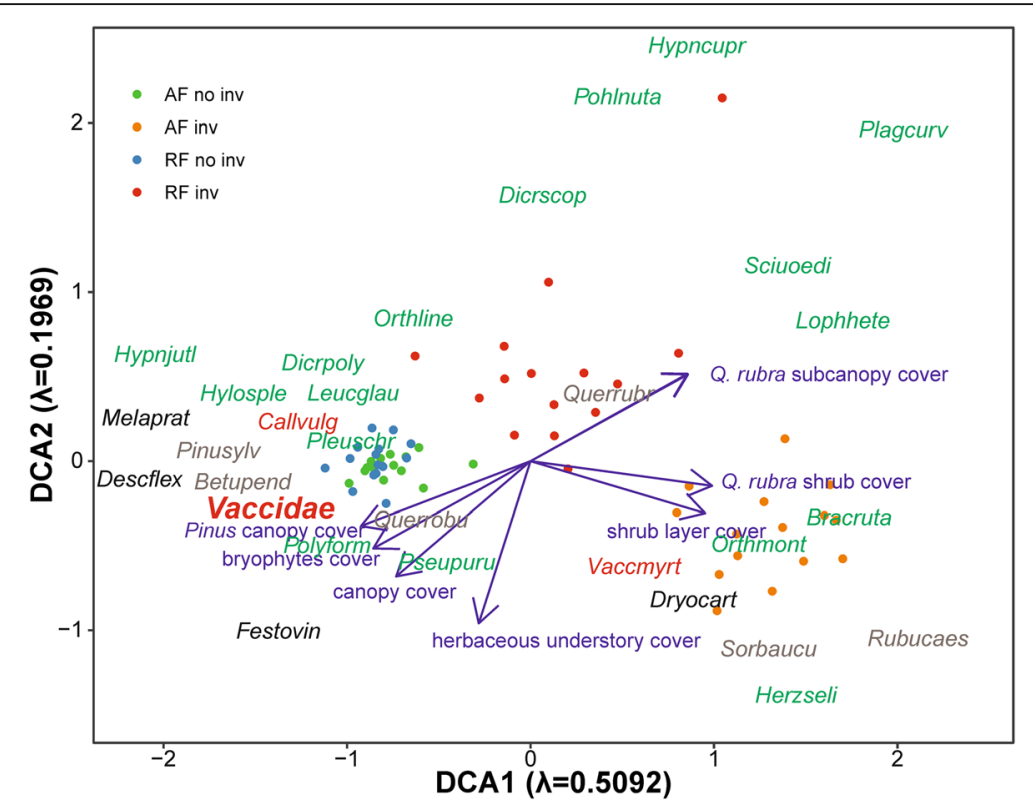

Fig. 1 DCA ordination of understory vegetation in four variants of pine forest: ancient (AF) and recent (RF) forests, without (no inv) and with (inv) Q. rubra. Italicized abbreviations (first four letters of genus and species names) indicate coordinates of species scores (bryophytes - green, ericoids - red, trees and shrubs - grey, other - black), with passively fitted vectors representing vegetation structure (violet, for fitness see Table 2). The label for the species studied (Vaccidae) was enlarged

schreberi and Polytrichum formosum) as well as grasses - Deschampsia flexuosa and Festuca ovina. In contrast, $V$. vitis-idaea avoided sites with high shrub cover.

\section{Impact of former land-use and $Q$. rubra occurrence on biomass allocation in shoots}

Our study revealed differences among $V$. vitis-idaea shoots from ancient and recent forests, as well as between pine and mixed forests (Fig. 2, Supporting Information I).

In ancient forest $V$. vitis-idaea reached higher aboveground biomass of shoots, as well as higher biomass of particular components - stems and leaves. It was also higher in ancient than recent forest and allocated more

Table 2 Parameters of vegetation structure variables fitted to the DCA analysis results (coefficient of determination $R^{2}$, and $p$ value were obtained based on permutation tests with 999 iterations)

\begin{tabular}{lllll}
\hline Variable - cover of & DCA1 & DCA2 & $\boldsymbol{R}^{\mathbf{2}}$ & $\boldsymbol{p}$ \\
\hline Canopy & -0.732 & -0.681 & 0.193 & 0.003 \\
Shrub layer & 0.952 & -0.307 & 0.506 & 0.001 \\
Herbaceous understory & -0.282 & -0.959 & 0.363 & 0.001 \\
Bryophytes & -0.857 & -0.515 & 0.802 & 0.001 \\
Pinus canopy & -0.924 & -0.383 & 0.192 & 0.002 \\
Q. rubra subcanopy & 0.856 & 0.518 & 0.776 & 0.001 \\
Q. rubra shrub & 0.989 & -0.146 & 0.449 & 0.001 \\
\hline
\end{tabular}

biomass to foliage than stems. We did not find differences in dry biomass, its allocation and height between Scots pine monocultures and mixed forests, however, we found higher water content in forest with Q. rubra as well as higher fresh biomass.

\section{Impact of former land-use and Q. rubra occurrence on} lingonberry shoot density, biomass, its allocation, water content and fruiting at the plot- and ecosystem-levels Vaccinium vitis-idaea reached the highest density, aboveground biomass, and biomass of particular components in the ancient Scots pine forest (Fig. 3, Supporting Information II). Differences between forests with and without Q. rubra were much higher than between ancient and recent forests. Biomass allocation patterns confirmed results from the individual shoot level higher foliage allocation in ancient pine forests. In contrast, fruit number and biomass were thirtyfold higher in ancient than recent pine forests and no fruiting individuals were found in forests with $Q$. rubra. At the ecosystem scale (i.e. accounting for $V$. vitis-idaea distribution patterns within $100 \mathrm{~m}^{2}$ plots) we found that Q. rubra introduction decreased all ecosystems services $>99 \%$ (Table 3 ), while forest land use discontinuity in pine forest decreased all services by $75 \%$, with the exception of fruit production, which decreased by $98 \%$. 

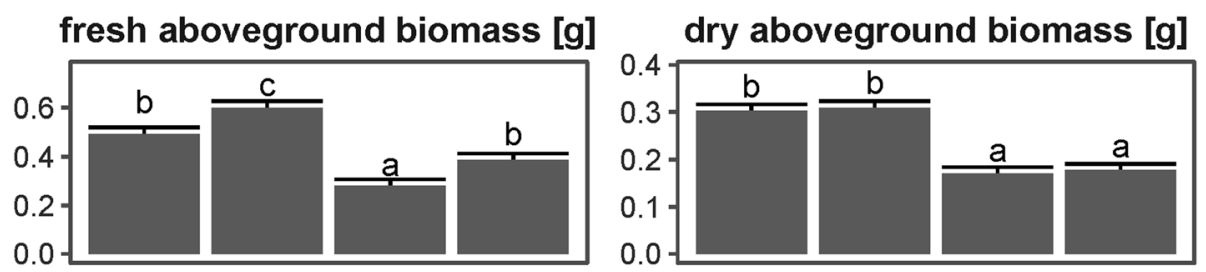

\section{aboveground biomass water content dry foliage biomass [g]}
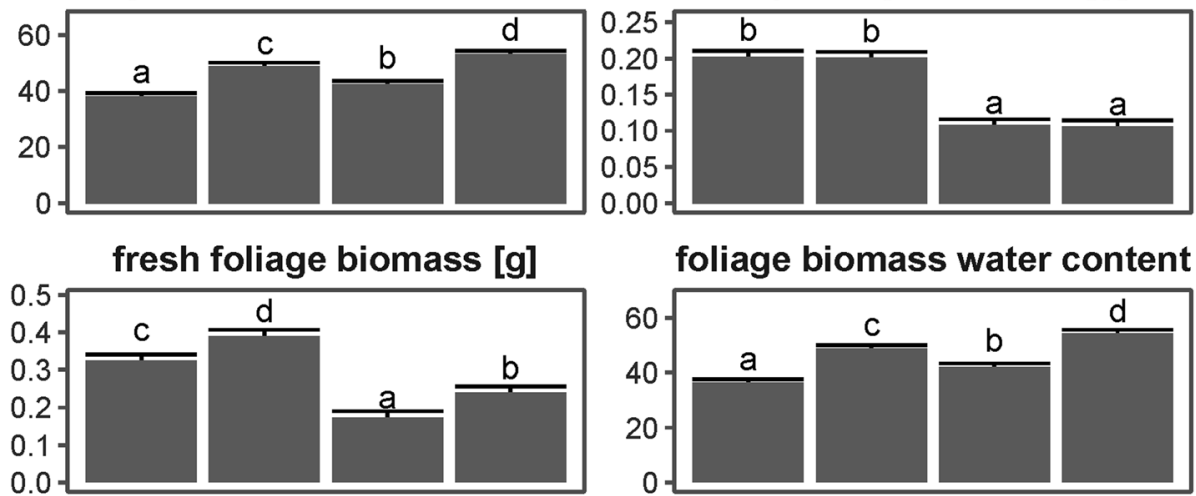

foliage biomass water content
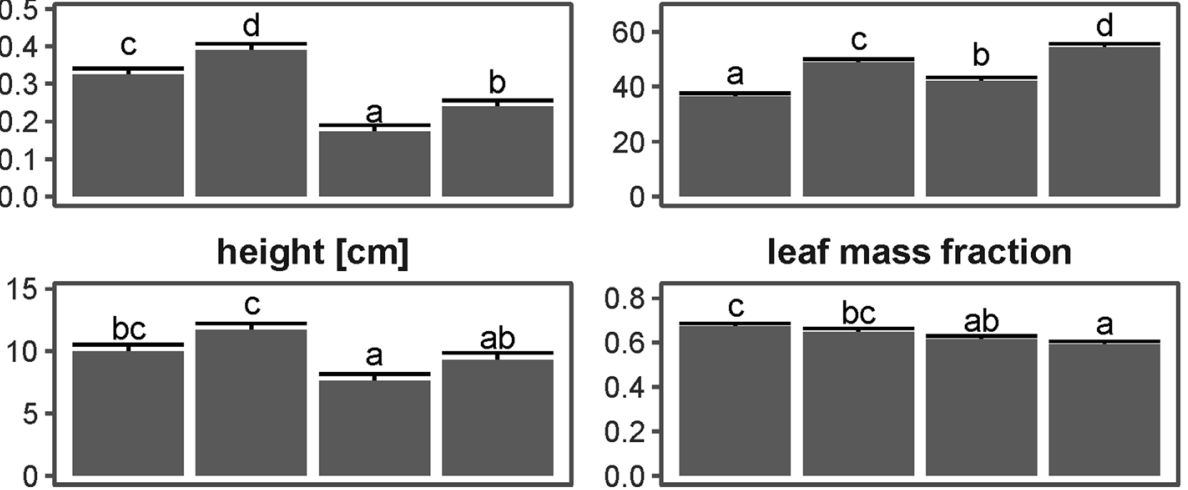

leaf mass fraction

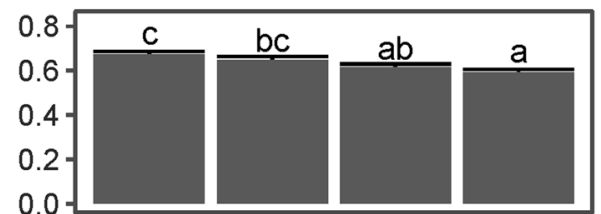

stem mass fraction

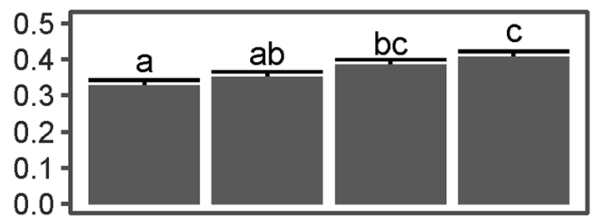

dry stem biomass [g]

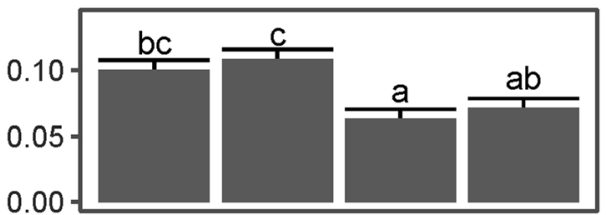

fresh stem biomass [g]

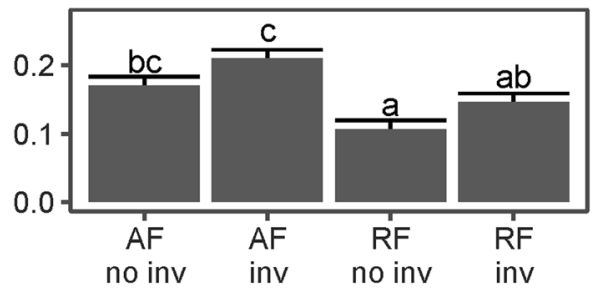

stem biomass water content

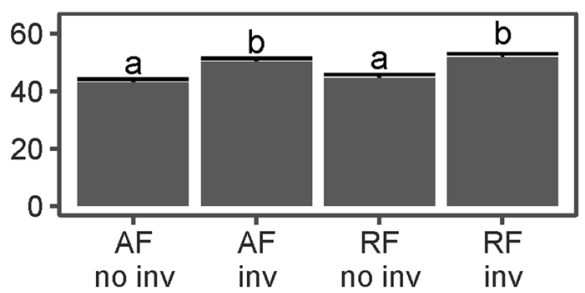

Variant

Fig. 2 Marginal (with excluded random effects) mean (+SE) individual biomass, its allocation, water content and height of $V$. vitis-idaea in four types of pine forest: ancient (AF) and recent (RF) forests without (no inv) and with (inv) $Q$. rubra, predicted by linear mixed-effects models ( $n=$ 400). Groups denoted by the same letters did not differ statistically significantly $(p>0.05)$ according to the Tukey posteriori tests. For models - see Supporting Information I

Biomass allocation and water content of fruiting and nonfruiting shoots in ancient and recent Scots pine forests Fruiting shoots of $V$. vitis-idaea were taller and had higher stem biomass and lower foliage biomass than non-fruiting shoots (Table 4, Fig. 4). We found higher total aboveground biomass in fruiting lingonberries in ancient forest, however fruiting plants in recent forest did not differ from non-fruiting plants in ancient forests. Stem mass fraction did not differ between fruiting and non-fruiting plants, but was higher in recent than ancient forest. For fruiting shoots we found that increasing leaf mass fraction decreased fruit mass fraction, and that 
dry aboveground biomass [ $\left.\mathrm{g} \mathrm{m}^{-2}\right]$ aboveground biomass water [ $\left.\mathrm{g} \mathrm{m}^{-2}\right]$
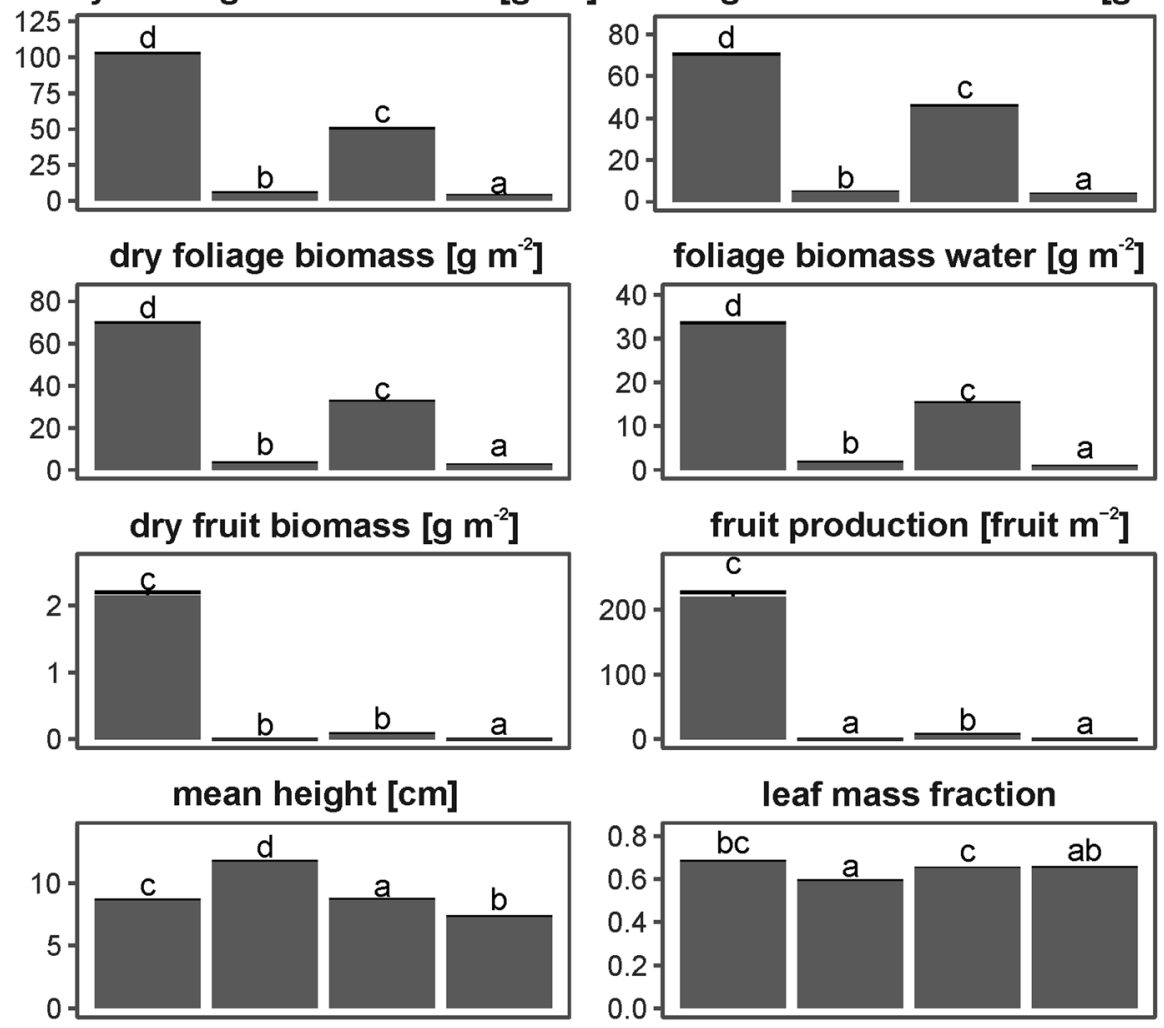

density [ind. $\mathrm{m}^{-2}$ ]

\section{stem mass fraction}
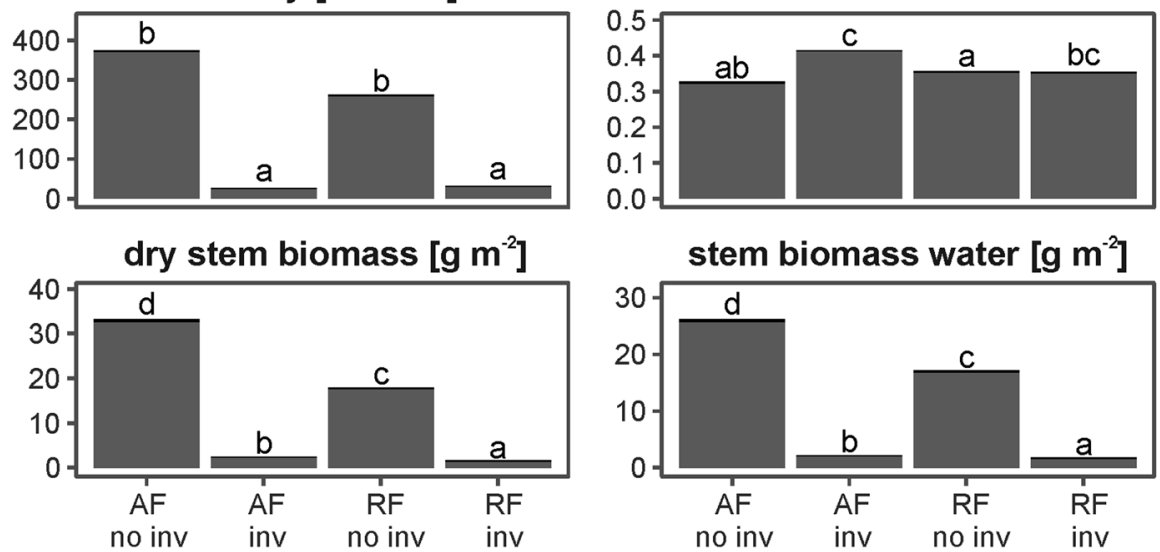

\section{Variant}

Fig. 3 Mean (+SE) plot level biomass, its allocation, water content, fruiting, density and height of $V$. vitis-idaea in four variants of pine forest: ancient (AF) and recent (RF) forests without (no inv) and with (inv) Q. rubra $(n=200)$. Groups denoted by the same letters did not differ statistically significantly $(p>0.05)$ according to the Tukey posteriori tests. For models - see Supporting Information II

this relationship was stronger in ancient than recent forest (Table 5, Fig. 5).

\section{Discussion}

Effect of land use history and forest community structure and composition on lingonberry occurrence

According to our expectations, forest land use continuity favoured V. vitis-idaea occurrence, both in the Scots pine and mixed, Scots pine-northern red oak, forests. This result reinforces the role of this species as an ancient woodland flora indicator (Matuszkiewicz et al. 2013). The high lingonberry abundance (described by plant cover and shoot density) was determined by the maintenance of the light coniferous forest with a singlespecies (P. sylvestris) and single-layer stand, both in ancient and recent forests. The weaker lingonberry 
Table $3 \mathrm{~V}$. vitis-idaea biomass, water and carbon storage (corrected by mean cover) at the ecosystem level. Decrease of analysed data was calculated with ancient pine forest without Q. rubra as a reference. Variants of the study: ancient (AF) and recent (RF) forests without (no inv) and with (inv) Q. rubra

\begin{tabular}{|c|c|c|c|c|}
\hline Variable & $\begin{array}{l}\text { Dry fruits biomass } \\
\left(\mathrm{g} \cdot \mathrm{ha}^{-1}\right)\end{array}$ & $\begin{array}{l}\text { Water stored in } \\
\text { biomass }\left(\mathbf{g} \cdot \mathrm{ha}^{-1}\right)\end{array}$ & $\begin{array}{l}\text { Dry aboveground } \\
\text { biomass }\left(g \cdot h a^{-1}\right)\end{array}$ & $\begin{array}{l}\text { Dry aboveground } \\
\text { biomass } C\left(\mathbf{g} \cdot \mathrm{ha}^{-1}\right)\end{array}$ \\
\hline AF no inv & 5821.6 & $188,345.0$ & $275,635.0$ & $122,657.6$ \\
\hline SE & 6.6 & 108.4 & 120.4 & 53.6 \\
\hline$A F$ inv & 0.0 & 72.5 & 8.28 & 36.8 \\
\hline SE & 0.0 & 0.1 & 0.1 & 0.0 \\
\hline decrease (\%) & 100.00 & 99.96 & 99.97 & 99.97 \\
\hline RF no inv & 99.3 & $62,198.0$ & $68,046.5$ & $30,280.7$ \\
\hline SE & 0.3 & 34.7 & 36.0 & 16.0 \\
\hline decrease (\%) & 98.29 & 66.98 & 75.31 & 75.31 \\
\hline RF inv & 0.0 & 11.0 & 10.6 & 4.7 \\
\hline SE & 0.0 & 0.1 & 0.1 & 0.1 \\
\hline decrease (\%) & 100.00 & 99.99 & 100.00 & 100.00 \\
\hline
\end{tabular}

condition noted in post-agricultural Scots pine monoculture (described by lower cover, shoot density and aboveground biomass) than in ancient pine forest, resulted from the early stage of lingonberry encroachment to new afforestation (Matuszkiewicz et al. 2014). Similar dependencies between land use history, tree stand structure and composition, and understory species occurrence were found for $V$. myrtillus (Woziwoda et al. 2019b), however, they were clearer in the case of lingonberry. This might be connected with higher light requirements and lower competitive abilities of $V$. vitisidaea than V. myrtillus (Ellenberg and Leuschner 2010). Also, we found that Q. rubra had stronger effects on understory vegetation than land-use legacy.

Results of this study are in line with Depauw et al. (2020). Studying herb layer structure and

Table 4 Differences in individual height, biomass and its allocation between fruiting and non-fruiting plants in ancient and recent forests, assessed using linear models ( $n=100$ per variant)

\begin{tabular}{|c|c|c|c|c|c|}
\hline Response & Variable & Estimate & SE & $t$ & $\operatorname{Pr}(>|t|)$ \\
\hline Mean height $(\mathrm{cm})$ & (Intercept) & 10.1095 & 0.2406 & 42.0183 & $<0.0001$ \\
\hline \multirow[t]{2}{*}{ Adj. $R^{2}=0.122$} & Land use: recent forest & 0.9530 & 0.2778 & 3.4303 & 0.0007 \\
\hline & Fruiting: yes & -1.8780 & 0.2778 & -6.7598 & $<0.0001$ \\
\hline Dry stem biomass (g) & (Intercept) & 0.1147 & 0.0049 & 23.5465 & $<0.0001$ \\
\hline \multirow[t]{2}{*}{ Adj. $R^{2}=0.071$} & Land use: recent forest & -0.0088 & 0.0056 & -1.5659 & 0.1182 \\
\hline & Fruiting: yes & -0.0309 & 0.0056 & -5.4852 & $<0.0001$ \\
\hline Dry foliage biomass (g) & (Intercept) & 0.1854 & 0.0081 & 22.7968 & $<0.0001$ \\
\hline \multirow[t]{2}{*}{ Adj. $R^{2}=0.141$} & Land use: recent forest & -0.0762 & 0.0094 & -8.1100 & $<0.0001$ \\
\hline & Fruiting: yes & 0.0114 & 0.0094 & 1.2151 & 0.2251 \\
\hline Dry aboveground biomass (g) & (Intercept) & 0.3953 & 0.0118 & 33.4828 & $<0.0001$ \\
\hline \multirow[t]{2}{*}{ Adj. $R^{2}=0.241$} & Land use: recent forest & -0.1209 & 0.0136 & -8.8674 & $<0.0001$ \\
\hline & Fruiting: yes & -0.0966 & 0.0136 & -7.0902 & $<0.0001$ \\
\hline Leaf mass fraction & (Intercept) & 0.4384 & 0.0111 & 39.4632 & $<0.0001$ \\
\hline \multirow[t]{2}{*}{ Adj. $R^{2}=0.469$} & Land use: recent forest & -0.0533 & 0.0128 & -4.1551 & $<0.0001$ \\
\hline & Fruiting: yes & 0.2355 & 0.0128 & 18.3591 & $<0.0001$ \\
\hline Stem mass fraction & (Intercept) & 0.2909 & 0.0088 & 33.1052 & $<0.0001$ \\
\hline \multirow[t]{2}{*}{ Adj. $R^{2}=0.232$} & Land use: recent forest & 0.1122 & 0.0101 & 11.0603 & $<0.0001$ \\
\hline & Fruiting: yes & 0.0057 & 0.0101 & 0.5597 & 0.5760 \\
\hline
\end{tabular}

$t$ - test statistic, adjusted (Adj.) $R^{2}$ - coefficient of determination 


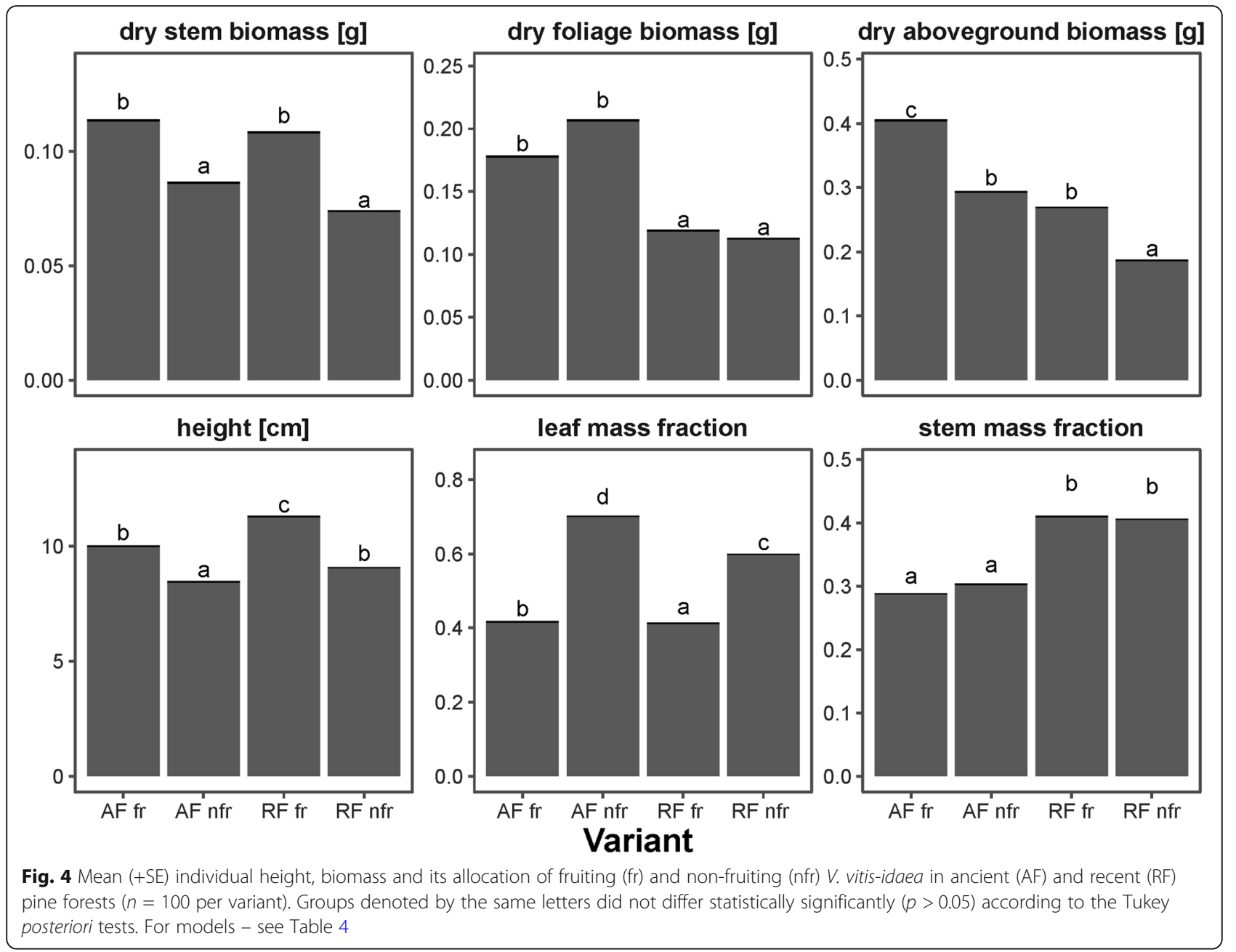

composition in semi-natural deciduous forests, they indicated that land-use history and light availability were the main, and more importantly, interacting environmental drivers of biodiversity and functional changes in forest understory. Decreases in the herb layer cover were correlated with decreasing light availability (i.e. canopy closures) and were greater in ancient than in recent forests (Depauw et al. 2020). The understory composition was controlled by local canopy characteristics, regulating light availability on the forest floor.

Table $\mathbf{5}$ Linear model of fruit mass fraction, as a function of leaf mass fraction and forest type (adjusted $R^{2}=0.590$ )

\begin{tabular}{lllll}
\hline Variable & Estimate & SE & $\boldsymbol{t}$ & $\operatorname{Pr}(>|\boldsymbol{t}|)$ \\
\hline (Intercept) & 0.5581 & 0.0202 & 27.6620 & $<0.0001$ \\
Leaf mass fraction & -0.6235 & 0.0433 & -14.3820 & $<0.0001$ \\
Land use: recent forest & -0.1203 & 0.0131 & -9.2140 & $<0.0001$ \\
\hline
\end{tabular}

Most of the herb layer components co-occurring with $V$. vitis-idaea in pine forests achieved low cover with the exception of $V$. myrtillus, indicating interspecific competition between these two ericaceous species. Both of them are susceptible to competition with grasses (Mohd et al. 2013), but in the forests studied this was noted only in very small patches dominated by clumps of Deschampsia flexuosa. Mosaic distribution of $V$. vitisidaea and $V$. myrtillus in forest understories were strongly determined by the canopy, subcanopy and shrub canopy openness (Fig. 1). Lingonberry occurrence was negatively correlated with overstory canopy closure, while bilberry occurrence was less dependent on canopy openness, and our results are in accordance with Mäkipää (1999). The necessary water resources were preserved by the epigeic mosses, growing in pine forests as dense wefts, e.g. Pleurozium schreberi and Pseudoscleropodium purum, or compact tall turfs Dicranum polysetum, Polytrichastrum formosum (Woziwoda et al. 2017), and the water was available 


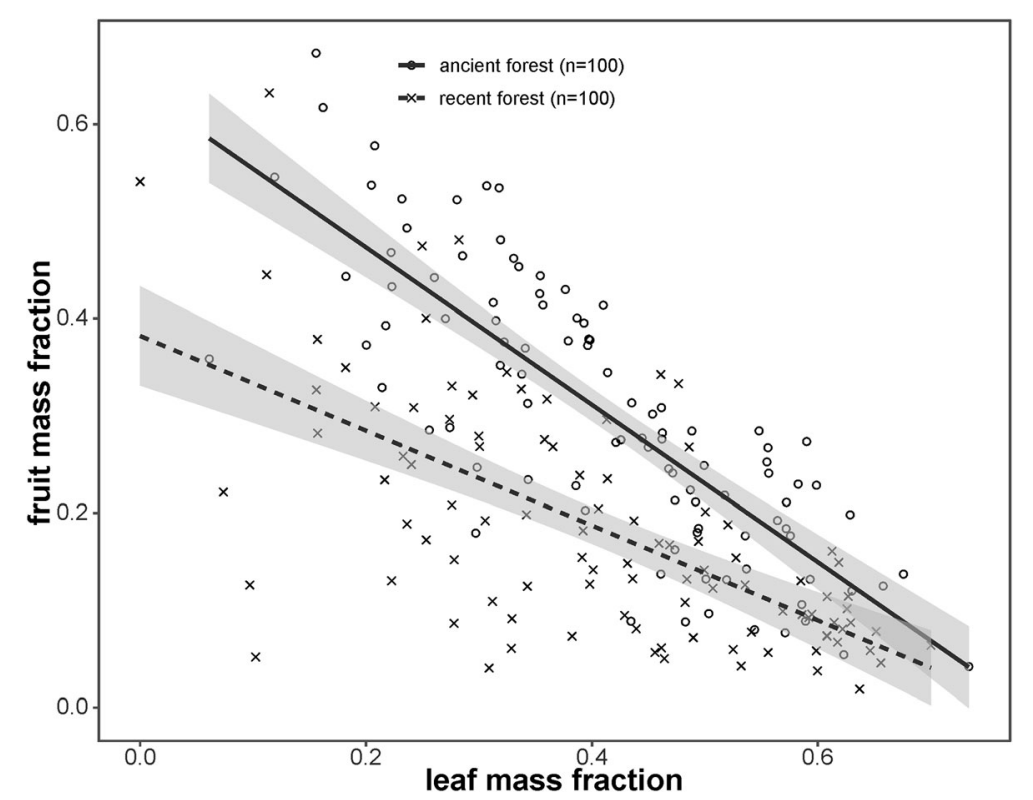

Fig. 5 Relationship between leaf mass fraction and fruit mass fraction in fruiting $V$. vitis-idaea shoots from ancient and recent forest $(n=100$ per variant). Model parameters in Table 4

to lingonberry rhizomes rooted in superficial soil layers (Ritchie 1955).

\section{Differences in aboveground biomass allocation as a survival strategy}

Studying individual lingonberry shoots, we revealed that in pine monocultures they were shorter, and allocated more biomass to leaves than to stems. However, leaves contained less water than steams, which could have resulted from more intensive water evaporation from leaf surfaces in sunny sites, or may have indicated the lingonberry growth strategy directed to decreasing water loss in sunny and dry sites (Ritchie 1955). Consequently, the higher water content noted in ramets under dense pine-oak canopies, both in ancient and recent forests, could result from limited water loss from leaves. However, some studies show that evapotranspiration of plants in shaded sites can be more intensive than in open areas (Ellenberg and Leuschner 2010). In the Scots pine-red oak forest lingonberry ramets grew taller, especially in ancient forest, actively searching for limited resources of dispersed sunlight. The lower lingonberry shoot density and lower dry aboveground biomass indicated its retreat from mixed forest.

$V$. vitis-idaea is a light demanding species, so the higher the canopy openness, the better the conditions for growth, and also for fruiting. High solar radiation is known as a positive factor in lingonberry yields both in the wild (especially with the absence or low competition of other understory species, Zvereva and Kozlov 2005), as well as in cultivation (Gustavsson 1997; Penhallegon
2006). It is related to the higher activity of pollinators observed in sunny sites (Rodríguez and Kouki 2015; Eckerter et al. 2019).

In this study we found that with occurrence of $Q$. rubra, lingonberry did not produce any berries. Fruiting shoots occurred in light pine monocultures, and plants growing in ancient forest were most productive. The interesting result of our study was that fruiting shoots grew taller and reached higher total biomass than nonfruiting shoots, both in recent and ancient forest. Similar results were found for other clonal plants (Kull 1995; Greer and McCarthy 2000), and they showed that fruiting may be governed by a threshold plant size, which is often required for sexual reproduction to take place. We also found that more of the dry biomass of fruiting shoots was allocated (besides fruits) to stems than to leaves; some shoots with berries were poorly leaved or even leafless (Fig. 4). In turn, non-fruiting shoots allocated more biomass to fraction of leaves. Generally, the higher the biomass allocation in vegetative organs (leaves and steams), the less fruit production. Such different biomass allocation indicates the functional differentiation of ramets into generative (fruiting) and vegetative (non-fruiting) shoots (Pitelka and Ashman 1985). It also confirms Marshall's theory on clonal integration of ramets, which refers to the sharing of materials or resources between ramets: photosynthetic products are transported by rhizomes from the source - in this case from leaves of vegetative shoots, to the target - fruiting shoots (Marshall 1990). Similar results were found in a study on biomass and leaf traits of 
twelve understory herbaceous plants - in most cases, generative plants had lower specific leaf area than vegetative plants (Jagodziński et al. 2016). Contrary to results of Depauw et al. (2020), we found greater plant height decreases under more closed canopy in recent than in ancient forests, however, this could be a species-specific reaction to changes in light conditions.

\section{Consequences of $Q$. rubra introduction for $V$. vitis-idaea and recommendation for forest management}

Our results clearly showed that high canopy density of Q. rubra in Scots pine forests had negative effects on lingonberry cover, growth and yield. The problem arises because once Q. rubra is introduced, it spreads effectively and spontaneously colonizes nearby patches of the Scots pine stands (Woziwoda et al. 2018, 2019b), where it has twice the level of seedling survival than beneath canopies of parental trees (Dyderski and Jagodziński 2019a, 2019b). Further transformation of pine forests to mixed Scots pine-red oak forests will result in progressive lingonberry withdrawal which means losses in native biodiversity, as well as decreased availability of NWFPs and loss of some ecosystem services, similarly as in the case of V. myrtillus (Woziwoda et al. 2019b).

Decline of some wild populations of $V$. vitis-idaea also means the loss of its genetic diversity (Debnath 2016). This phenomenon, known as "genetic erosion" of plants (Ahuja and Jain 2016), has negative ecological and economic consequences. Studies of Kalt et al. (2007) and Debnath and Sion (2009) showed that wild lingonberry clones produce berries with higher antioxidant activity and anthocyanin content than cultivars. Therefore they are permanently used for genetic improvement of already domesticated plants to increase the quantity and quality of fruits (Persson and Gustavsson 2001; Debnath and Sion 2009). The loss of still largely unexplored wildgrown clones can limit the possibility of commercial use of lingonberry, and it is perceived as a potential threat to agricultural sustainability in the billion dollar lingonberry market (e.g. Burt and Penhallegon 2003; Turtiainen and Nuutinen 2012; Debnath 2016). Decreasing number of lingonberry localities in combination with the growing popularity of wild healthy food may give rise to another problem - overexploitation of the remnants of wild populations (Ticktin 2004, 2015).

The growing interest in $V$. vitis-idaea forces its preservation (Garkava-Gustavsson et al. 2005; Weiss et al. 2019; Chamberlain et al. 2019). Simultaneously, it activates silvicultural measures directed to increase lingonberry yield (Pettenella et al. 2019; Wolfslehner 2019). Tree stand thinning and moderate tree stand disturbance have already been recommended to increase lingonberry cover and yield (Mäkipää 1999; Hautala et al. 2001; Bergstedt et al. 2008; Hekkala et al. 2014; Johnson et al. 2014) and to improve lingonberry chemical quality (Vyas et al. 2015; Vilkickyte et al. 2019). This study revealed that the forest management scheme concentrated on transformation of pine monocultures to mixed Scots pine-red oak forests also needs improvement to consider lingonberry and other species sources of NWFPs. In order to limit the decline of these valuable plants, and hence to meet the targets of the Convention of Biological Diversity (CBD 2010) and sustainable use of forests (Wolfslehner et al. 2019), Q. rubra introduction in European mesic Scots pine forests should be limited, and its spontaneous spread should also be controlled.

\section{Conclusions}

Our study revealed the synergistic impact of land-use legacy (ancient and recent forest) and invasive tree $(Q$. rubra) introduction on biomass allocation of $V$. vitisidaea, as well on its life strategy. Lingonberry is an important element of coniferous forests understories in terms of ecosystem services, and it also has cultural and economic importance. Therefore, the discontinuity of forest land use and occurrence of invasive trees decreases $V$. vitis-idaea cover, biomass, fruit production and carbon sequestration. However, decreases caused by invasive trees is higher than by land-use legacy alone. Such effects were also clear at the individual shoot level - we found higher height and higher biomass allocation to stems than to foliage in less suitable conditions. We also found that fruiting and non-fruiting shoots of lingonberry differ in biomass allocation patterns - fruiting shoots allocated less biomass to foliage than nonfruiting ones.

In the age of high interest in forest ecosystem services (Maes et al. 2012; Dickie et al. 2014; Felipe-Lucia et al. 2018), and discussion about usage of alien tree species as alternatives to native species (Thurm et al. 2018; Jandl et al. 2019) which are susceptible to climate change, our results clearly indicate disruption of ecosystem services provided by an important understory plant. Similarly to other studies of Q. rubra effects on biodiversity (Woziwoda et al. 2014a; Chmura 2020), ecosystem services (Woziwoda et al. 2019b) and natural regeneration of native woody species (Woziwoda et al. 2019a), we argue that regardless of land-use legacy, introduction of habitat-modifying tree species (transformers sensu Richardson et al. 2000) lead to decline in abundance of species crucial for ecosystem functioning. Therefore, for conservation of delivery of ecosystem services, we suggest limiting the introduction of Q. rubra in areas with abundant $V$. vitis-idaea, especially in forests with continuous land-use history. 


\section{Supplementary Information}

The online version contains supplementary material available at https://doi. org/10.1186/s40663-021-00287-y.

\section{Additional file 1: Supporting Information I: Table 1 Supp.}

Differences in individual biomass, its allocation, water content and height among study variants, assessed using linear mixed-effects models $(n=$ 400)

Additional file 2: Supporting Information II: Table_2_Supp

Differences in plot-level biomass, its allocation, water content, fruiting density and height among study variants, assessed using linear models and GLMs $(n=200)$

\section{Acknowledgements}

We thank to Iwona Kałuzińska, Izabela Lenarcik and Marlena Wiśniewska, master students of nature conservation in Faculty of Biology and Environmental Protection, University of Lodz, for their assistance in laborious field and lab work. We kindly thank Dr. Lee E. Frelich (The University of Minnesota Center for Forest Ecology, USA) for linguistic revision of the manuscript.

\section{Authors' contributions}

BW conceived the ideas, revised the literature, designed field and lab methodology and collected the data; MKD designed methodology of statistical analyses and analysed the data; BW and MKD wrote original draft and edited the manuscript; AMJ supervised the formal analyses and revised the final version. All authors gave final approval for publication.

\section{Funding}

The study was financially supported by the Faculty of Biology and Environmental Protection, University of Lodz and the Institute of Dendrology, Polish Academy of Sciences, Kórnik, Poland.

\section{Availability of data and materials}

The datasets used and analysed during the current study are available from the corresponding author on reasonable request.

\section{Ethics approval and consent to participate}

Not applicable.

\section{Consent for publication}

Not applicable.

\section{Competing interests}

The authors declare that they have no competing interests.

\section{Author details}

${ }^{1}$ Faculty of Biology and Environmental Protection, Department of Geobotany and Plant Ecology, University of Lodz, Banacha 12/16, PL-90-237 Łódź Poland. ${ }^{2}$ Institute of Dendrology, Polish Academy of Sciences, Parkowa 5, PL-62-035 Kórnik, Poland.

Received: 26 June 2020 Accepted: 18 January 2021

Published online: 02 February 2021

\section{References}

Ahuja MR, Jain SM (eds) (2016) Genetic diversity and Erosion in plants: case histories, Sustain Dev Biodiv 8, vol 2. https://doi.org/10.1007/978-3-31925954-3

Baltrūnaitè $L$ (2001) Feeding habits, food niche overlap of red fox Vulpes vulpes and pine marten Martes martes in hilly moraine highland, Lithuania. Ekologija 2:27-32 http://www.elibrary.It/resursai/LMA/Ekologija/Ek-27.pdf. Accessed 20 Dec 2019

Barbier S, Gosselin F, Balandier P (2008) Influence of tree species on understory vegetation diversity and mechanisms involved - a critical review for temperate and boreal forests. For Ecol Manag 254(1):1-15. https://doi.org/10. 1016/j.foreco.2007.09.038

Bates D, Mächler M, Bolker B, Walker S (2015) Fitting linear mixed-effects models using Ime4. J Stat Soft 67:1-48. https://doi.org/10.18637/jss.v067.i01
Bergstedt J, Hagner M, Milberg P (2008) Effects on vegetation composition of a modified forest harvesting and propagation method compared with clearcutting, scarification and planting. Appl Veg Sci 11:159-168. https://doi. org/10.3170/2007-7-18343

Burt L, Penhallegon RH (2003) Economic evaluation of lingonberry production in Oregon. Oregon State University. EM 8847. https://smallfarms.oregonstate. edu/sites/agscid7/files/em8847.pdf. Accessed 20 Dec 2019

CBD Convention of Biological Diversity (2010) COP 10 DecisionX/2: Strategic Plan for biodiversity 2011-2020. http://www.cbd.int/decision/cop/?id=12268. Accessed 4 May 2019

Chamberlain J, Small C, Baumflek M (2019) Sustainable forest management for nontimber products. Sustainability 11:2670. https://doi.org/10.3390/ su11092670

Chmura D (2020) The spread and role of the invasive alien tree Quercus rubra (L.) in novel forest ecosystems in Central Europe. Forests 11(5):586. https://doi. org/10.3390/f11050586

Collier M, Farrell EP (2007) The environmental impact of planting broadleaved trees on acid-sensitive soils. Literature review. COFORD, Dublin

Debnath SC (2016) Genetic diversity and erosion of berries. In: Ahuja MR, Jain SM (eds) Genetic diversity and Erosion in plants: case histories, Sustain Dev Biodiv 8, vol 2, pp 75-130. https://doi.org/10.1007/978-3-319-25954-3_3

Debnath SC, McRae KB (2001) In vitro culture of lingonberry (Vaccinium vitis-idaea L.). Small Fruits Rev 1(3):3-19. https://doi.org/10.1300/J301v01n03 02

Debnath SC, Sion M (2009) Genetic diversity, antioxidant activities, and anthocyanin contents in lingonberry. Int J Fruit Sci 9(2):185-199. https://doi. org/10.1080/15538360903005061

Depauw L, Perring M, Landuyt D, Maes S, Blondeel H, De Lombaerde E, Brumelis G, Brunet J, Closset-Kopp D, Czerepko J, Decocq G, den Ouden J, Gawrys R, Hardtle W, Hedl R, Heinken T, Heinrichs S, Jaroszewicz B, Kopecky M, Liepina I, Macek M, Malis F, Schmidt W, Smart SM, Ujhazy K, Wulf M, Verheyen K (2020) Light availability and land-use history drive biodiversity and functional changes in forest herb layer communities. J Ecol. https://doi.org/10.1111/ 1365-2745.13339

Dickie IA, Bennett BM, Burrows LE, Nuñez MA, Peltzer DA, Porté A, Richardson DM, Rejmanek M, Rundel PW, van Wilgen BW (2014) Conflicting values: ecosystem services and invasive tree management. Biol Invasions 16:705719. https://doi.org/10.1007/s10530-013-0609-6

Dyderski MK, Chmura D, Dylewski $Ł$, Horodecki P, Jagodziński AM, Pietras M, Robakowski P, Woziwoda B (2020) Biological Flora of the British Isles: Quercus rubra. J Ecol 108:1199-1225. https://doi.org/10.1111/1365-2745.13375

Dyderski MK, Jagodziński AM (2019a) Seedling survival of Prunus serotina Ehrh., Quercus rubra L. and Robinia pseudoacacia L. in temperate forests of Western Poland. Forest Ecol Manag 450:117498. https://doi.org/10.1016/j.foreco.2019. 117498

Dyderski MK, Jagodziński AM (2019b) Similar impacts of alien and native tree species on understory light availability in a temperate forest. Forests 10:951. https://doi.org/10.3390/f10110951

Eckerter T, Buse J, Förschler M, Pufal G (2019) Additive positive effects of canopy openness on European bilberry (Vaccinium myrtillus) fruit quantity and quality. Forest Ecol Manag 433:122-130. https://doi.org/10.1016/j.foreco.2018.10.059

Ellenberg H, Leuschner C (2010) Vegetation Mitteleuropas mit den Alpen. 6 Aufl. Ulmer-Verlag, Stuttgart

Ellenberg H, Weber HE, Düll R, Wirth V, Werner W, Paulißen D (2001) Zeigerwerte von Pflanzen in Mitteleuropa. Scri Geobot 18:1-248

Felipe-Lucia MR, Soliveres S, Penone C, Manning P, Plas F, van der Boch S, Boch S, Prati D, Ammer C, Schall P, Gossner MM, Bauhus J, Buscot F, Blaser S, Bluthgen N, de Frutos A, Ehbrecht M, Frank K, Goldmann K, Hansel F, Jung K, Kahl T, Nauss T, Oelmann Y, Pena R, Polle A, Renner S, Schloter M, Schoning I, Schrumpf M, Schulze ED, Solly E, Sorkau E, Stempfhuber B, Tschapka M, Weisser WW, Wubet T, Fischer M, Allan E (2018) Multiple forest attributes underpin the supply of multiple ecosystem services. Nat Commun 9:4839. https://doi.org/10.1038/s41467-018-07082-4

Felton A, Nilsson U, Sonesson J, Felton AM, Roberge J-M, Ranius T, Ahlstrom M, Bergh J, Bjorkman C, Boberg J, Drossler L, Fahlvik N, Gong P, Holmstrom E, Keskitalo ECH, Klapwijk MJ, Laudon H, Lundmark T, Niklasson M, Nordin A, Pettersson M, Stenlid J, Stens A, Wallertz K (2016) Replacing monocultures with mixed-species stands: ecosystem service implications of two production forest alternatives in Sweden. Ambio 45(2):124-139. https://doi.org/10.1007/ s13280-015-0749-2

Garkava-Gustavsson L, Persson HA, Nybom H, Rumpunen K, Gustavsson BA Bartish IV (2005) RAPD-based analysis of genetic diversity and selection of 
lingonberry (Vaccinium vitis-idaea L.) material for ex situ conservation. Genet Resour Crop Evol 52(6):723-735. https://doi.org/10.1007/s10722-003-6123-4

Gilliam FS (2007) The ecological significance of the herbaceous layer in temperate forest ecosystems. BioScience 57:845-858. https://doi.org/10.1641/ B571007

Górriz E (2019) NWFPs in a bioeconomy spectrum: opening opportunities for cross-sectoral links. In: Wolfslehner B, Prokofieva I, Mavsar R (eds) Non-wood forest products in Europe: seeing the forest around the trees. What science can tell us 10. European Forest Institute, Joensuu, pp 100-103. https://www. efi.int/sites/default/files/files/publication-bank/2019/efi_wsctu_10_2019.pdf. Accessed 4 May 2019

Greer GK, McCarthy BC (2000) Patterns of growth and reproduction in a natural population of the fern Polystichum acrostichoides. Am Fern J 90:60-76 https://www.jstor.org/stable/1547415. Accessed 4 May 2019

Gustavsson BA (1997) Breeding strategies in lingonberry culture (Vaccinium vitis-idaea L. ). Acta Hortic 46:129-138. https://doi.org/10.17660/ActaHortic.1997.446.18

Hamunen K, Kurttila M, Miina J, Peltol R, Tikkanen J (2019) Sustainability of Nordic non-timber forest product-related businesses - a case study on bilberry. Forest Policy Econ 109:102002. https://doi.org/10.1016/j.forpol.2019.102002

Hautala H, Tolvanen A, Nuortila C (2001) Regeneration strategies of dominant boreal forest shrubs in response to selective removal of understorey layers. J Veg Sci 12:503-510. https://doi.org/10.2307/3237002/pdf

Hedwall P-O, Brunet J, Nordin A, Bergh J (2013) Changes in the abundance of keystone forest floor species in response to changes of forest structure. J Veg Sci 24:296-306. https://doi.org/10.1111/j.1654-1103.2012.01457.x

Hekkala A-M, Tarvainen O, Tolvanen A (2014) Dynamics of understory vegetation after restoration of natural characteristics in the boreal forests in Finland. Forest Ecol Manag 330:55-66. https://doi.org/10.1016/j.foreco.2014.07.001

Hill MO, Gauch HG (1980) Detrended correspondence analysis: an improved ordination technique. Vegetatio 42:47-58. https://doi.org/10.1007/BF00048870

Hjalmarsson I, Ortis R (2001) Lingonberry: botany and horticulture. In: Janick J (ed) Horticultural Reviews 27, chapter 3. John, New York, pp 79-123. https:// doi.org/10.1002/9780470650813.ch3

Huber P, Hujala T, Kurttila M, Wolfslehner B, Vacik H (2017) Application of multi criteria analysis methods for a participatory assessment on non-wood forest products in two European case studies. Forest Policy Econ. https://doi.org/10. 1016/j.forpol.2017.07.003

Hunter ML (1999) Maintaining biodiversity in Forest ecosystems. Cambridge University Press, Cambridge

Jacquemart AL, Thompson JD (1996) Floral and pollination biology of three sympatric Vaccinium (Ericaceae) species in the upper Ardennes, Belgium. Can Jot 74(2):210-221

Jagodziński AM, Dyderski MK, Rawlik K, Kątna B (2016) Seasonal variability of biomass, total leaf area and specific leaf area of forest understory herbs reflects their life strategies. Forest Ecol Manag 374:71-81. https://doi.org/10. 1016/j.foreco.2016.04.050

Jandl R, Spathelf P, Bolte A, Prescott CE (2019) Forest adaptation to climate change - is non-management an option? Ann Forest Sci 76:48. https://doi. org/10.1007/s13595-019-0827-x

Jaroszewicz B, Pirożnikow E, Sagehorn R (2008) The European bison as seed dispersers: the effect on the species composition of a disturbed pine forest community. Botany 86(5):475-484. https://doi.org/10.1139/B08-012

Johnson S, Strengbom J, Kouki J (2014) Low levels of tree retention do not mitigate the effects of clearcutting on ground vegetation dynamics. Forest Ecol Manag 330:67-74. https://doi.org/10.1016/j.foreco.2014.06.031

Kalt W, Howell AB, MacKinnon SL, Goldman IL (2007) Selected bioactivities of Vaccinium berries and other fruit crops in relation to their phenolic contents. J Sci Food Agric 87:2279-2285. https://doi.org/10.1002/jsfa.2985

Kardell L (1980) Occurrence and production of bilberry, lingonberry and raspberry in Sweden's forests. Forest Ecol Manag 2:285-298. https://doi.org/ 10.1016/0378-1127(79)90055-0

Krasnov V, Shelest Z, Boiko S, Gulik I, Sieniawski W (2015) The diet of the roe deer (Capreolus capreolus) in the forest ecosystems of Zhytomirske Polesie of the Ukraine. Forest Res Paper 76(2):184-190. https://doi.org/10. 1515/frp-2015-018

Kull T (1995) Genet and ramet dynamics of Cypripedium calceolus in different habitats. Clonality in plant communities-Proceedings of the 4th international workshop on clonal plants, Visegrád, Hungary. Abstr Bot 19:95104 https://www.jstor.org/stable/43519486. Accessed 4 May 2019

Kuznetsova A, Brockhoff PB, Christensen RHB (2017) ImerTest: tests in linear mixed effects models. J Stat Softw 82. https://doi.org/10.18637/jss.v082.i13
Kylli P, Nohynek L, Puupponen-Pimiä R, Westerlund-Wikström B, Leppänen T, Welling J, Moilanen E, Heinonen M (2011) Lingonberry (Vaccinium vitis-idaea) and European cranberry (Vaccinium microcarpon) Proanthocyanidins: isolation, identification, and bioactivities. J Agric Food Chem 59:3373-3384

Laird SA, McLain RJ, Wynberg RP (2010) Wild product governance. In: Laird SA, McLain RJ, Wynberg RP (eds) Wild product governance. Earthscan Inc., London, pp 1-14

Landuyt D, De Lombaerde E, Perring MP, Hertzog LR, Ampoorter E, Maes SL, De Frenne P, Ma SY, Proesmans W, Blondeel H, Sercu BK, Wang B, Wasof S, Verheyen K (2019) The functional role of temperate forest understorey vegetation in a changing world. Glob Chang Biol 00:1-17. https://doi.org/10. 1111/gcb.14756

Lenth R (2019) Emmeans: estimated marginal means, aka least-squares means. https://cran.r-project.org/package=emmeans. Accessed 03 Apr 2020

Luby JJ, Ballington JR, Darpar AD, Pliszka K, Austin ME (1991) Blueberries and cranberries (Vaccinium). Acta Hortic 290:391-456. https://doi.org/10.17660/ ActaHortic.1991.290.9

Maes J, Egoh B, Willemen L, Liquete C, Vihervaara P, Schägner JP, Grizzetti B, Drakou EG, La Notte A, Zulian G, Bouraoui F, Paracchini ML, Braat L, Bidoglio G (2012) Mapping ecosystem services for policy support and decision making in the European Union. Ecosyst Serv 1:31-39. https://doi.org/10.1016/ j.ecoser.2012.06.004

Magni Diaz CR (2004) Reconstitution de l'introduction de Quercus rubra L. en Europe et conséquences génétiques dans les populations allochtones. Dissertation, ENGREF, Paris

Maiz-Tome L (2016) Vaccinium vitis-idaea. The IUCN red list of threatened species 2016: e.T18748884A78457217. https://doi.org/10.2305/IUCN.UK.2016-1.RLTS

Mäkipää R (1999) Response patterns of Vaccinium myrtillus and V. vitis-idaea along nutrient gradients in boreal forest. J Veg Sci 10(1):17-26 https://www. jstor.org/stable/3237156. Accessed 4 May 2019

Manninen OH, Peltola R (2013) Effects of picking methods on the berry production of bilberry (Vaccinium myrtillus), lingonberry (V. vitis-idaea) and crowberry (Empetrum nigrum ssp. hermaphroditum) in northern Finland. Silv Fenn 7(3):1-12. https://doi.org/10.14214/sf.972

Marozas V, Straigyte L, Šepetienie J (2009) Comparative analysis of alien oak (Quercus rubra L.) and native common oak (Quercus robur L.) vegetation in Lithuania. Acta Biol Univ Daugavpiliensis 9(1):19-24 https://www. researchgate.net/publication308146070. Accessed 4 May 2019

Marshall C (1990) Source-sink relations of interconnected ramets. In: van Groenendael J, de Kroon $\mathrm{H}$ (eds) Clonal growth in plants: regulation and function. SPB Academic Publishing, The Hague, pp 23-41.

Matuszkiewicz JM, Kowalska A, Kozłowska A, Roo-Zielińska E, Solon J (2013) Differences in plant-species composition, richness and community structure in ancient and post-agricultural pine forests in Central Poland. Forest Ecol Manag 310:567-576. https://doi.org/10.1016/j.foreco.2013.08.060

Matuszkiewicz JM, Kowalska A, Solon J, Degórski M, Kozłowska A, Roo-Zielińska E, Zawiska I, Wolski J (2014) Long-term evolution models of post-agricultural forests. IGiPZ PAN, Warsaw

Matuszkiewicz W (2001) A guide for the identification of polish plant communities. Wydawnictwo Naukowe PWN, Warsaw (in Polish)

MEA (2005) Millennium Ecosystem Assessment. Ecosystems and human wellbeing. Island Press, Washington, DC https://www.millenniumassessment.org/ documents. Accessed 4 May 2019

Miina J, Pukkala T, Hotanen J-P, Salo K (2010) Optimizing the joint production of timber and bilberries. Forest Ecol Manag 259:2065-2071. https://doi.org/10. 1016/j.foreco.2010.02.017

Mohd F, Ramli A, Cornulier T, Johnson D (2013) Partitioning of soil phosphorus regulates competition between Vaccinium vitis-idaea and Deschampsia cespitosa. Ecol Evol Aberdeen 3(12):4243-4252

Nestby R, Percival D, Martinussen I, Opstad N, Rohloff J (2011) The European blueberry (Vaccinium myrtillus) and the potential for cultivation. A review. Eur J Plant Sci Biotech 5:5-16

Nicolescu V-N, Vor T, Mason WL, Bastien J-C, Brus R, Henin J-M, Kupka I, Lavnyy V, La Porta N, Mohren F, Petkova K, Redei K, Stefancik I, Wasik R, Peric S, Hernea C (2018) Ecology and management of northern red oak (Quercus rubra L. syn. Q. borealis F. Michx.) in Europe: a review. Forestry:1-14. https://doi.org/ 10.1093/forestry/cpy032

Oksanen J, Blanchet FG, Kindt R, Legendre P, Michin PR, O'Hara RB, Simpson GL, Solymos P, Henry M, Stevens H, Wagner H (2018) "vegan" 2.3.3. - Community Ecology Package. http://CRAN.R-project.org/package=vegan. Accessed 4 May 2019 
Peltola R, Hallikainen V, Tuulentie S, Naskali A, Manninen O, Similä J (2014) Social licence for the utilization of wild berries in the context of local traditional rights and the interests of the berry industry. Barents Stud Peoples Econ Polit 1(2):24-49 https://lauda.ulapland.fi/handle/10024/59411. Accessed 4 May 2019

Penhallegon RH (2006) Lingonberries - a production quide. Extension horticulture faculty (Lane County), Oregon State University. PNW 583-E:1-12

Persson H, Gustavsson BA (2001) The extent of clonality and genetic diversity in lingonberry (Vaccinium vitis-idaea L.) revealed by RAPDs and leaf-shape analysis. Mol Ecol 10(6):1385-1397. https://doi.org/10.1046/j.1365-294X.2001. 01280.x

Peterken GF (1974) A method for assessing woodland flora for conservation using indicator species. Biol Conserv 6:239-245. https://doi.org/10.1016/00063207(74)90001-9

Pettenella D, Corradini G, Da Re R, Lovrić M, Vidale E (2019) NWFPs in Europe consumption, markets and marketing tools. In: Wolfslehner B, Prokofieva I, Mavsar R (eds) Non-wood forest products in Europe: seeing the forest around the trees. What science can tell us 10. European Forest Institute, Joensuu, pp 31-53. https://www.efi.int/sites/default/files/files/publicationbank/2019/efi_wsctu_10_2019.pdf. Accessed 4 May 2019

Pitelka LF, Ashman JW (1985) Physiology and integration of ramets in clonal plants. In: Jackson BC, Buss LW, Cook RE (eds) Population biology and evolution of clonal organisms. Yale University Press, New Haven, CT, pp 399 435

Pouta E, Sievänen T, Neuvonen M (2006) Recreational wild berry picking in Finland - reflection of a rural lifestyle. Soc Nat Resour 19(4):285-304. https:// doi.org/10.1080/08941920500519156

Pretzsch H (2009) Forest dynamics, growth, and yield. From Measurement to Model. Springer, Berlin

R Core Team (2019) R: A language and environment for statistical computing. R Foundation for Statistical Computing, Vienna

Radusheva P, Milkova-Tomova I, Nikolova K, Buhalova D, Aleksieva J, Eftimov T, Krustev S (2017) Investigation of health effect of fruit juice from lingonberry (Vaccinium vitis-idea) via physicochemical methods. J IMAB 23(4):1731-1736. https://doi.org/10.5272/jimab.2017234.1731

Reicis K, Bradley RL, Joanisse G, Houlec D, Tremblay S, Barrettec M, Wotherspoon A (2020) Pre-commercial thinning enhances competitive traits of boreal ericaceous shrubs and reduces soil fertility. Forest Ecol Manag 458:117801. https://doi.org/10.1016/j.foreco.2019.117801

Richardson DM, Pyšek P, Rejmánek M, Barbour MG, Panetta FD, West CJ (2000) Naturalization and invasion of alien plants: concepts and definitions. Divers Distrib 6:93-107. https://doi.org/10.1046/j.1472-4642.2000.00083.x

Ritchie JC (1955) Biological flora of the British Isles: Vaccinium vitis-idaea L. J Eco 43(2):701-708 https://www.jstor.org/stable/2257030. Accessed 4 May 2019

Rodríguez A, Kouki J (2015) Emulating natural disturbance in forest management enhances pollination services for dominant Vaccinium shrubs in boreal pinedominated forests. Forest Ecol Manag 350:1-12. https://doi.org/10.1016/j. foreco.2015.04.029

Seeland K, Staniszewski P (2007) Indicators for a European cross-country state-ofthreat assessment of non-timber forest products and services. Small-Scale For 6:411-422. https://doi.org/10.1007/s11842-007-9029-8

Šišák L, Riedl M, Dudik R (2016) Non-market non-timber forest products in the Czech Republic-their socio-economic effects and trends in forest land use. Land Use Policy 50:390-398. https://doi.org/10.1016/j.landusepol.2015.10.006

Stephens D (2012) Pollination ecology and the floral rewards of Vaccinium myrtilloides and $V$. vitis-idaea (Ericaceae). Dissertation, University of Saskatchewan, Saskatoon. http://hdl.handle.net/10388/ETD-2012-06-518. Accessed 20 May 2019

Sutherland IJ, Bennett EM, Gergel SE (2016) Recovery trends for multiple ecosystem services reveal non-linear responses and long-term tradeoffs from temperate forest harvesting. Forest Ecol Manag 374:61-70. https://doi.org/10. 1016/j.foreco.2016.04.037

Tahvanainen V, Miina J, Kurttila M (2019) Climatic and economic factors affecting the annual supply of wild edible mushrooms and berries in Finland. Forests 10(5):385. https://doi.org/10.3390/f10050385

Thurm EA, Hernandez L, Baltensweiler A, Ayan S, Rasztovits E, Bielak K, Zlatanov TM, Hladnik D, Balic B, Freudenschuss A, Buchsenmeister R, Falk W (2018) Alternative tree species under climate warming in managed European forests. Forest Ecol Manag 430:485-497. https://doi.org/10.1016/j.foreco.2018. 08.028
Ticktin T (2004) The ecological implications of harvesting non-timber forest products. Appl Ecol 41(1):11-21. https://doi.org/10.1111/j.1365-2664.2004. 00859

Ticktin T (2015) The ecological sustainability of non-timber forest product harvest. Principles and method. In: Shackleton CM, Pandey AK, Ticktin T (eds) Ecological sustainability for non-timber Forest products: dynamics and case studies of harvesting. Taylor \& Francis Group http://ebookcentral.proquest. com/lib/uhm/detail.action?doclD=1987357. Accessed 4 May 2019

Timoshok EE (2000) The ecology of bilberry (Vaccinium myrtillus L.) and cowberry (Vaccinium vitis-idaea L.) in Western Siberia. Russ J Ecol 37(1):8-13 (Translated from Ekologiya 1:11-16). https://link.springer.com/article/10.1007/BF02799719. Accessed 4 May 2019

Turtiainen M (2015) Modelling bilberry and cowberry yields in Finland: different approaches to develop models for forest planning calculations. Dissertationes Forestales:56. https://doi.org/10.14214/df.185

Turtiainen M, Miina J, Salo K, Hotanen J-P (2013) Empirical prediction models for the coverage and yields of cowberry in Finland. Silva Fenn 47(3). https:// www.silvafennica.fi/pdf/article1005.pdf

Turtiainen M, Nuutinen T (2012) Evaluation of information on wild berry and mushroom markets in European countries. Small-Scale For 11(1):131-145. https://doi.org/10.1007/s11842-011-9173-z

Turtiainen M, Salo K, Saastamoinen O (2011) Variations of yield and utilisation of bilberries (Vaccinium myrtillus L.) and cowberries (V. vitis-idaea L.) in Finland. Silva Fenn 45(2):237-251. https://doi.org/10.14214/sf.115

Venables WN, Ripley BD (2002) Modern applied statistics with S, Statistics and Computing. Springer New York, New York

Vidale E, Dare R, Pettenella D (2014) Global trade in NWFP and position of EU. In: Wong J, Prokofieva I (eds) The state of the European NWFP. StarTree report D1.3., pp 9-21 http://star-tree.eu/images/deliverables/WP1/D1_3_SOSR_nov2 015.pdf. Accessed 4 May 2019

Vidale E, Dare R, Pettenella D (2015) Trends, rural impacts and future developments of regional WFP market. In: StarTree Deliverable D3.2. FP7 Project no. 311919 KBBE.2012.1.2-06 https://www.researchgate.net/ publication/327136729. Accessed 4 May 2019

Vilkickyte G, Raudonis R, Motiekaityte V, Vainoriene R, Burdulis D, Viskelis J, Raudone $L$ (2019) Composition of sugars in wild and cultivated lingonberries (Vaccinium vitis-idaea L.). Molecules 24:4225. https://doi.org/10.3390/ molecules 24234225

Vyas P, Curran NH, Igamberdiev AU, Debnath SC (2015) Antioxidant properties of lingonberry (Vaccinium vitis-idaea L.) leaves within a set of wild clones and cultivars. Can J Plant Sci 95:663-669. https://doi.org/10.4141/CJPS-2014-400

Wagner S, Fischer H, Huth F (2011) Canopy effects on vegetation caused by harvesting and regeneration treatments. Eur J Forest Res 130:17-40. https:// doi.org/10.1007/s10342-010-0378-z

Whigham DF (2004) Ecology of woodland herbs in temperate deciduous forests. Ann Rev Ecol Evol S 35:583-621. https://doi.org/10.1146/annurev.ecolsys.35. 021103.105708

Wiersum KF, Wong JLG, Vacik H (2018) Perspectives on non-wood Forest product development in Europe. Int Forest Rev 20(2):250-262. https://doi.org/10. 1505/146554818823767546

Wolfslehner B (2019) Policy implications. In: Wolfslehner B, Prokofieva I, Mavsar R (eds) Non-wood forest products in Europe: seeing the forest around the trees. What science can tell us 10. European Forest Institute, Joensuu, pp 111-113. https://www.efi.int/sites/default/files/files/publication-bank/2019/ efi_wsctu_10_2019.pdf. Accessed 4 May 2019

Wolfslehner B, Prokofieva I, Mavsar R (eds) (2019) Non-wood forest products in Europe: seeing the forest around the trees. What science can tell us $10 . \mathrm{EFI}$ https://www.efi.int/sites/default/files/files/publication-bank/2019/efi_wsctu_1 0_2019.pdf. Accessed 4 May 2019

Woziwoda B, Dyderski MK, Jagodziński AM (2019b) Effects of land use change and Quercus rubra introduction on Vaccinium myrtillus performance in Pinus sylvestris forests. Forest Ecol Manag 440:1-11. https://doi.org/10.1016/j.foreco. 2019.03.010

Woziwoda B, Dyderski MK, Kobus S, Parzych A, Jagodziński AM (2019a) Natural regeneration and recruitment of native Quercus robur and introduced $Q$. rubra in European oak-pine mixed forests. Forest Ecol Manag 449:117473. https://doi.org/10.1016/j.foreco.2019.117473

Woziwoda B, Kopeć D, Witkowski J (2014a) The negative impact of intentionally introduced Quercus rubra L. on a forest community. Acta Soc Bot Pol 83(1): 39-49. https://doi.org/10.5586/asbp.2013.035 
Woziwoda B, Krzyżanowska A, Dyderski MK, Jagodziński AM, Stefańska-Krzaczek E (2018) Propagule pressure, presence of roads, and microsite variability influence dispersal of introduced Quercus rubra in temperate Pinus sylvestris forest. Forest Ecol Manag 428:35-45. https://doi.org/10.1016/j.foreco.2018.06.033

Woziwoda B, Parzych A, Kopeć D (2014b) Species diversity, biomass accumulation and carbon sequestration in the understorey of postagricultural Scots pine forests. Silva Fenn 48(5):id 1119 p 23. https:// silvafennica.fi/pdf/article1119.pdf. Accessed 4 May 2019

Woziwoda B, Potocki M, Sagan J, Zasada M, Tomusiak R, Wilczyński S (2014c) Commercial forestry as a vector of alien tree species - the case of Quercus rubra L. introduction in Poland. Balt For 20:131-141 https://www. balticforestry.mi.lt/bf/PDF_Articles/2014-20[1]. Accessed 4 May 2019

Woziwoda B, Staniaszek-Kik M, Stefańska-Krzaczek E (2017) Assemblages of native bryophytes in secondary forests with introduced Quercus rubra. Nord J Bot 35(1):111-120. https://doi.org/10.1111/njb.01121

Yao Y, Vieira A (2007) Protective activities of Vaccinium antioxidants with potential relevance to mitochondrial dysfunction and neurotoxicity. Neurotoxicology 28:93-100. https://doi.org/10.1016/j.neuro.2006.07.015

Zarzycki K, Trzcińska-Tacik H, Różański W, Szeląg Z, Wołek J, Korzeniak U (2002) Ecological indicator values of vascular plants of Poland. W. Szafer Inst Bot, Polish Academy of Science, Kraków

Zeileis A, Kleiber C, Jackman S (2008) Regression models for count data in R. J Stat Softw 27:1-21. https://doi.org/10.18637/jss.v027.i08

Zvereva EL, Kozlov MV (2005) Growth and reproduction of dwarf shrubs, Vaccinium myrtillus and V. vitis-idaea, in a severely polluted area. Basic Apll Ecol 6:261-274. https://doi.org/10.1016/j.baae.2004.11.003

\section{Submit your manuscript to a SpringerOpen ${ }^{\circ}$ journal and benefit from:}

- Convenient online submission

- Rigorous peer review

- Open access: articles freely available online

- High visibility within the field

- Retaining the copyright to your article

Submit your next manuscript at $\boldsymbol{\nabla}$ springeropen.com 